\title{
Correlations Between Stability Statistics of Forage Production in Elephant Grass
}

\author{
Rogerio F. Daher ${ }^{1}$, Bruna R. S. Menezes ${ }^{2}$, Geraldo A. Gravina ${ }^{1}$, Benedito F. de Souza Filho ${ }^{3}$, \\ Ana Kesia Faria Vidal ${ }^{1}$, Wanessa Fracesconi Stida ${ }^{1}$, Rafael Souza Freitas ${ }^{1}$, Alexandre Gomes de Souza ${ }^{1}$, \\ Antonio Alonso Cecon Novo ${ }^{4}$, Antonio Vander Pereira ${ }^{5} \&$ Paulo Ricardo dos Santos ${ }^{1}$ \\ ${ }^{1}$ Universidade Estadual do Norte Fluminense Darcy Ribeiro, Campos dos Goytacazes, RJ, Brazil \\ ${ }^{2}$ Universidade Federal Rural do Rio de Janeiro, Seropédica, RJ, Brazil \\ ${ }^{3}$ Empresa de Pesquisa Agropecuária do Estado do Rio de Janeiro, Campos dos Goytacazes, RJ, Brazil \\ ${ }^{4}$ Instituto Federal Fluminense, Bom Jesus do Itabapoana, Rio de Janeiro, RJ, Brazil \\ ${ }^{5}$ Empresa Brasileira de Pesquisa Agropecuária, Juiz de Fora, Minas Gerais, MG, Brazil
}

Correspondence: Bruna R. S. Menezes, Universidade Federal Rural do Rio de Janeiro, Postal Code: 23851-970, Seropédica, RJ, Brazil. E-mail: brunarafamenezes@hotmail.com

Received: February 9, 2019

doi:10.5539/jas.v12n1p118

\author{
Accepted: October 7, 2019 Online Published: December 15, 2019 \\ URL: https://doi.org/10.5539/jas.v12n1p118
}

\begin{abstract}
Elephant grass (Pennisetum purpureum Schum.) is an important forage plant in the tropics and the potential of genotypes depends on the genotype $\times$ environment interaction effects. The objective of this study was to evaluate and compare different stability methods of forage production of 53 elephant grass genotypes, in Campos dos Goytacazes, Rio de Janeiro State, Brazil. The experiment lasted two years, a total of ten cuts with randomized block experimental design with two replications. The analysis of variance was applied to data from dry matter production (DMP), subjected to stability analysis using the following methods: Yates and Cochran, Plaisted and Peterson, ecovalence Wrickie, Kang and Phan, Lin and Bins, and Annicchiarico. The Yates and Cochran method showed more stable genotypes but being less productive. Plaisted and Peterson and ecovalence Wrickie methods presented a Spearman correlation equal to 1 , so it is not recommended to implement them concurrently. Lin and Bins showed a strong negative correlation with the average being a method that indicates the genotype also very stable and productive. This method correlates with Annicchiarico, which also indicates productive genotypes by the confidence index. The genotypes most stable among the methods were: Pusa Napier 2, Taiwan A-143 and Merckeron Comum.
\end{abstract}

Keywords: breeding, dry matter production, G×E interaction, Pennisetum, spearman

\section{Introduction}

The forage productions obtained in pastures originate largely the competitiveness of Brazilian cattle industry (Barcellos et al., 2008). The elephant grass (Pennisetum purpureum Schum.) because of its high yield potential and quality is one of the most suitable forage for intensive systems of milk production in pasture (Cóser et al., 2008).

The cattle raising is a common activity on the properties of North of Rio de Janeiro State, Brazil, thus having great importance in the economy and sustainability of municipalities in the region. In the municipality of Campos dos Goytacazes, RJ, about $40 \%$ of farms have livestock as their main activity (Souza et al., 2009). Like most of the country, in northern Fluminense, the intensive rearing system has fodder as its main source of feed for cattle.

The efficient use of forage and pasture for animal feed is one of the surest ways to increase productivity, thereby reducing production costs. Whereas the cost of deploying and maintaining an elephant grass plantation depend on the cultivar used in planting, selection of clones of higher productivity, improved nutritional value and higher stability make it more economical exploration activity of dairy cattle, providing a greater margin of profit for the producer. The selection of new genotypes of elephant grass more adapted to soil and climatic conditions of North 
Fluminense may result in an increase in forage supply, especially in the dry season, thus mitigating the effects of seasonality on production.

The elephant grass is used prominently in the Brazilian dairy livestock (Moreira et al., 2008). There is a need of developing new varieties for the production of milk by means of plant breeding (Leão et al., 2012). Enhanced cultivars are a common need to dairy farmers across the country, and the demand for new forage cultivars adapted to different ecosystems is intense. Stability is the response predictability in different environmental conditions (Viana et al., 2014). Studies of stability parameters are important because they allow us to identify genotypes with predictable behavior and responding to environmental variations (Cruz et al., 2012).

The method of Yates and Cochran (1938) consists in the joint analysis of experiments, in which the variation of the environment within each genotype is used for an estimate of stability. The Plaisted and Peterson (1959) method, besides quantifying, identifies the most stable genotypes. The stability parameter in Wricke's method is called ecovalence and presents as advantages and disadvantages of the method proposed by Plaisted and Peterson (1959) (Cruz et al., 2012).

The method by Lin and Binns (1988) is a nonparametric test that evaluates the deviation of cultivars behavior in the environments and, therefore, estimates a stability. The method also considers a genotype test and behavior of a hypothetical genotype, or a measure of adaptability (Murakami et al., 2004). Annicchiarico's (1992) methodology is also used to study adaptability and stability (Schmildt \& Cruz, 2005).

Therefore, the objective of this study was to evaluate and compare different stability statistics of the forage production of 53 genotypes of elephant grass in successive cuts made over time at conditions of Campos dos Goytacazes, RJ, Brazil.

\section{Materials and Methods}

The experiment was conducted at the State Center for Research on Bioenergy and Waste Recovery, located in the city of Campos dos Goytacazes, Rio de Janeiro State, Brazil (Coordinates: $21^{\circ} 19^{\prime} 23^{\prime \prime} \mathrm{S}$ latitude and $41^{\circ} 19^{\prime} 40^{\prime \prime} \mathrm{W}$ longitude; elevation of 20 to $30 \mathrm{~m}$ ) in the area of the Unit for Research Support of the Center for Agricultural Sciences and Technology (CCTA/UENF).

The experiment was composed of fifty-three genotypes of elephant grass (treatments) from the Active Germplasm Bank of Elephant grass of Universidade Estadual do Norte Fluminense Darcy Ribeiro (UENF), identified in Table 1. 
Table 1. Identification of fifty-three genotypes of elephant grass

\begin{tabular}{|c|c|c|c|}
\hline Identification & Genotype & Identification & Genotype \\
\hline 1 & Elefante da Colômbia & 28 & Mole de Volta Grande \\
\hline 2 & Mercker & 29 & Porto Rico \\
\hline 3 & Três Rios & 30 & Napier \\
\hline 4 & Napier Volta Grande & 31 & Merckeron Comum \\
\hline 5 & Mercker Santa Rita & 32 & Teresópolis \\
\hline 6 & Pusa Napier $n^{\circ} 2$ & 33 & Taiwan A-26 \\
\hline 7 & Gigante de Pinda & 34 & Duro de Volta Grande \\
\hline 8 & Napier Goiano & 35 & Mercker Comum de Pinda \\
\hline 9 & Mercker S.E.A & 36 & Turrialba \\
\hline 10 & Taiwan A-148 & 37 & Taiwan A-146 \\
\hline 11 & Porto Rico 534-B & 38 & Cameroon-Piracicaba \\
\hline 12 & Taiwan A-25 & 39 & Taiwan A-121 \\
\hline 13 & Albano & 40 & Vrukwona \\
\hline 14 & Híbrido Gigante da Colômbia & 41 & T241-Piracicaba \\
\hline 15 & Pusa Gigante Napier & 42 & IAC-Campinas \\
\hline 16 & Elefante Híbrido 534-A & 43 & Elefante Cachoeiro de Itapemirim \\
\hline 17 & Costa Rica & 44 & Capim-Cana D’África \\
\hline 18 & Cubano de Pinda & 45 & Gramafante \\
\hline 19 & Merckeron de Pinda & 46 & Roxo \\
\hline 20 & Merckeron Pinda México & 47 & Guaçu/IZ.2 \\
\hline 21 & Mercker 86 México & 48 & Cuba-116 \\
\hline 22 & Taiwan A-144 & 49 & King Grass \\
\hline 23 & Napier S.E.A & 50 & Vruckwona Africano \\
\hline 24 & Taiwan A-143 & 51 & Cameroon \\
\hline 25 & Pusa Napier $n^{0} 1$ & 52 & IJ $7141 \mathrm{cv}$ EMPASC 306 \\
\hline 26 & Elefante de Pinda & 53 & Pasto Panamá \\
\hline 27 & Mineiro & & \\
\hline
\end{tabular}

Planting was performed on April 25, 2008 by distributing whole stems into the furrows, positionated with their base in contact with the apex of the next plant in the bottom of the groove, in spaced lines at $50 \mathrm{~cm}$ in $10 \mathrm{~cm}$ deep, followed by $100 \mathrm{~kg} \mathrm{ha}^{-1} \mathrm{P}_{2} \mathrm{O}_{5}$. After 50 days of planting, fertilization was complemented with coverage of $25 \mathrm{~kg} \mathrm{ha}^{-1} \mathrm{~N}$.

The experimental design was a randomized block design with two replications. The experimental unit consisted of two rows spaced three meters by 0.5 meters between rows and $3 \mathrm{~m}$ between plots and are considered useful only $1.5 \mathrm{~m}$ of the lines, totaling $2,625 \mathrm{~m}^{2}$, neglecting the ends of each row.

After the establishment phase, all genotypes were cut close to the ground in October 3, 2008. After each cut was made coverage fertilization with $60 \mathrm{~kg} \mathrm{ha}^{-1}$ of $\mathrm{K}_{2} \mathrm{O}$ and $50 \mathrm{~kg} \mathrm{ha}^{-1}$ of $\mathrm{N}$, beginning the phase of data collection. The ten evaluation cuts occurred on the following dates: 5/12/08; 04/02/09, 14/04/09, 18/07/09, 15/10/09, 15/12/09; 08/03/10, 12/05/10, 17/09/10 and 03/12/10.

The trait evaluated was dry matter production (DMP). Plants that were $1.5 \mathrm{~m}$ within each plot were weighed immediately after cutting. Then, sub-samples collected, chopped and conditioned in paper bags identified, weighed and placed in an oven at $65{ }^{\circ} \mathrm{C}$ for 72 hours. Then the samples were weighed again to obtain the air-dried sample (ADS), according to the methodology described by Silva and Queiroz (2004).

Individual variance analysis was performed, followed by joint variance analysis. The stability methods employed were Yates and Cochran (1938), Plaisted and Peterson (1959), Wricke (1965), Lin and Binns (1988), Annicchiarico (1992) and Kang and Phan (1991). In this work, the weights of Kang and Phan (1991) were made in relation to methods Yates and Cochran (1938), Plaisted and Peterson (1959) and Wricke (1965). For the comparison between the methods was performed by Spearman rank correlation (Steel et al., 1997). For this analysis all statistics were classified according to the descending order. Statistical analyzes used in this work were performed using the program GENES-Computer Application in Genetics and Statistics (Cruz, 2013). 


\section{Results and Discussion}

The values of mean squares, averages and coefficients of experimental variation obtained by individual variance analysis, involving the elephant grass genotypes in Campos dos Goytacazes, in ten cuts are shown in Table 2. Significant differences among treatments were observed $(\mathrm{P}<0.05)$ for most of the cuts except the first and the sixth cut which were not significant and significant $(\mathrm{P}<0.05)$, respectively. The average dry matter production was $6.53 \mathrm{tha}^{-1}$, and ranged from 4.18 to $9.32 \mathrm{tha}^{-1}$, covering the seventh and first cut, respectively (Table 2). The DM yields obtained in this study were similar to those described by Meinerz et al. (2011), where it evaluated the genotype Merckeron Pinda in two planting systems, agroecologico and convercional. The average of $6 \mathrm{t} \mathrm{ha}^{-1} \mathrm{cuts}^{\mathrm{s}}$ in total of eight in the convecional system in this study was observed. According Lista (2008) in his study in Campos dos Goytacazes, RJ, Brazil, to evaluate the potential of 10 genotypes and two cultivars of elephant grass under irrigation found average of about $15 \mathrm{tha}^{-1}$ of dry matter in cut times 42, 56 and 70 days. Lima et al. (2007) evaluated for 9 months, 12 elephant grass genotypes in North Fluminense, and these DM yield by cutting ranged from 7.3 to $14.5 \mathrm{tha}^{-1}$.

Table 2. Mean squares, means and coefficients of variation of dry matter production obtained from the analysis of variance, involving fifty-three elephant grass genotypes, in the ten cuts evaluated

\begin{tabular}{lllllllllllll}
\hline \multirow{2}{*}{ SV } & \multicolumn{10}{c}{ Cut } \\
\cline { 2 - 18 } & 1 & 2 & 3 & 4 & 5 & 6 & 7 & 8 & 9 & 10 \\
\hline GMS & $12.50 \mathrm{~ns}$ & $4.16^{*}$ & $9.59^{*}$ & $9.27^{*}$ & $3.56^{*}$ & $1.96^{* * *}$ & $2.80^{*}$ & $2.13^{*}$ & $3.07^{*}$ & $6.26^{*}$ \\
RMS & 15.21 & 2.464 & 5.19 & 4.98 & 1.935 & 1.36 & 1.706 & 1.334 & 1.901 & 3.313 & \\
Mean & 9.32 & 7.13 & 9.15 & 7.34 & 4.95 & 5.30 & 4.18 & 5.65 & 5.34 & 7.00 & 6.536 \\
CV(\%) & 41.86 & 22.00 & 24.91 & 30.43 & 28.08 & 22.04 & 31.26 & 20.46 & 25.8 & 25.99 & 27.283 \\
\hline
\end{tabular}

Note. ${ }^{* * *},{ }^{* *}$ and ${ }^{*}$ significant at the level of 10,1 and $5 \%$ of probability by $\mathrm{F}$ test, respectively ${ }^{1 /}$ Mean square values multiplied by $10^{3}$.

DMP: Dry matter production; SV: Source of variation; Degree of freedon of Genotype SV $=52$; Degree of freedon of Residue SV = 52; GMS: Genotype Mean Square; RMS: Residue Mean Square; CV: Coefficient of variation.

The values of residual mean squares (RMS) obtained from individual variance analysis (for environment) of dry matter production (DMP) (Table 2) resulted in a relation between the largest and the smallest value of RMS equal to 11.40 , indicating a high degree of heterogeneity of variance in individually evaluated environments, thereby precluding the inclusion of all environments in joint variance analysis. Considering an acceptable proportion 7:1 (Pimentel Gomes, 2009) discarding the first cut was performed, then obtaining the ratio of 3.89 between the highest and lowest value of RMS for others nine environments (cuts) indicating relative homogeneity of variances enabling the use of these environments in the joint analysis of variance (Table 3 ).

Table 3. Summary of joint variance analysis for the trait dry matter production (DMP) involving 53 genotypes in 9 cuts

\begin{tabular}{lll}
\hline SV & DF & DMP (Mean squares) \\
\hline Block & 1 & 31.5176 \\
Genotype & 52 & $13.576^{*}$ \\
Error A & 52 & 7.7487 \\
Cut & 8 & $251.4040^{* *}$ \\
Error B & 8 & 3.3148 \\
G $\times$ C & 416 & $3.6581^{* *}$ \\
Error C & 416 & 2.0555 \\
\hline CV error a(\%) & & 44.702 \\
CV error b(\%) & 98.096 \\
CV error c(\%) & 23.023 \\
\hline
\end{tabular}

Note. ${ }^{* *}$ and * significant at the level of 1 and $5 \%$ of probability by $\mathrm{F}$ test, respectively. 
Significant differences by the $\mathrm{F}$ test for the sources of variation genotype, cut and genotype $\times$ cut were observed. The significance of the interaction suggests the study of stability, in order to indicate genotypes with predictable behavior and exhibit productive genotypes.

With respect to the method of Yates and Cochran (1938), it was found that genotypes had the lowest mean squared estimation (Table 4) were 49, 34, 33, 2, 31, 10, 46, 43, 3, 5, 15, 30, 40, 32, 18, 44, 4, 7, 21 and 24. Considering the ranking of general average productivity (Table 4), the genotype 49 , which is the most stable, occupied 48th among 53 positions, far below the overall average. The genotypes, 6, 31 and 24, the latter two being in accordance with the results of Yates and Cochran method, occupied positions 18th, 5th and 19th in the ranking of the most productive, respectively.

Table 4. Values of average dry matter production and stability parameters of Yates and Cochran (Y\&C), Plaisted and Peterson $(\theta \%)$, Wricke ( $\omega$ i \%), Lin and Binns (LB), Annicchiarico (Ann \%) and Kang and Phan associated with Yates and Cochran $(\mathrm{K}+\mathrm{Y} \& \mathrm{C})$; Plaisted and Peterson $(\mathrm{K}+\theta \%)$ and Wricke $(\mathrm{K}+\mathrm{Wi})$ methods

\begin{tabular}{|c|c|c|c|c|c|c|c|c|c|}
\hline Genotype & Average & $\mathrm{Y} \& \mathrm{C}$ & $\theta(\%)$ & $\omega \mathrm{i}(\%)$ & LB & Ann (\%) & $\mathrm{K}+\mathrm{Y} \& \mathrm{C}$ & $\mathrm{K}+\theta(\%)$ & $\mathrm{K}+\mathrm{Wi}$ \\
\hline 1 & 6.5256 & 15.96 & 3.76 & 3.53 & 8.75 & 96.39 & 66 & 66 & 66 \\
\hline 2 & 4.7942 & 2.24 & 0.22 & 0.43 & 15.61 & 76.11 & 55 & 53 & 53 \\
\hline 3 & 4.4685 & 3.43 & 1.94 & 1.93 & 18.5 & 68.4 & 62 & 85 & 85 \\
\hline 4 & 6.1642 & 4.86 & 0.83 & 0.96 & 9.2 & 95.36 & 45 & 44 & 44 \\
\hline 5 & 5.8994 & 3.56 & 0.54 & 0.71 & 10.27 & 92.68 & 46 & 44 & 44 \\
\hline 6 & 6.4967 & 6.53 & 0.41 & 0.59 & 7.62 & 101.11 & 42 & 24 & 24 \\
\hline 7 & 6.6862 & 4.95 & 2.52 & 2.44 & 7.69 & 103.49 & 34 & 56 & 56 \\
\hline 8 & 5.6259 & 5.37 & 0.74 & 0.88 & 11.46 & 85.35 & 62 & 54 & 53 \\
\hline 9 & 5.1786 & 8.28 & 0.94 & 1.06 & 13.81 & 76.58 & 80 & 65 & 65 \\
\hline 10 & 4.6793 & 2.31 & 0.84 & 0.97 & 16.6 & 72.98 & 58 & 69 & 69 \\
\hline 11 & 6.3005 & 5.64 & 0.68 & 0.83 & 8.71 & 97.72 & 47 & 35 & 35 \\
\hline 12 & 6.734 & 8.28 & 3.03 & 2.89 & 8.32 & 102.58 & 49 & 58 & 58 \\
\hline 13 & 5.9784 & 11.12 & 1.2 & 1.29 & 9.48 & 89.51 & 76 & 58 & 58 \\
\hline 14 & 5.4596 & 8.27 & 0.57 & 0.73 & 12.1 & 82.11 & 75 & 52 & 52 \\
\hline 15 & 5.4022 & 3.86 & 1.82 & 1.83 & 13 & 83.78 & 56 & 75 & 75 \\
\hline 16 & 6.78 & 8.8 & 1.27 & 1.35 & 6.84 & 102.67 & 50 & 39 & 39 \\
\hline 17 & 6.9976 & 27.24 & 7.03 & 6.39 & 7.29 & 98.58 & 62 & 62 & 62 \\
\hline 18 & 6.0599 & 4.51 & 0.1 & 0.32 & 9.39 & 94.84 & 48 & 34 & 34 \\
\hline 19 & 6.4342 & 13.4 & 3.73 & 3.5 & 9.3 & 95.42 & 66 & 69 & 69 \\
\hline 20 & 5.4046 & 15.81 & 3.86 & 3.62 & 13.7 & 76.87 & 92 & 94 & 94 \\
\hline 21 & 4.8715 & 5.28 & 1.51 & 1.56 & 15.9 & 72.68 & 68 & 76 & 76 \\
\hline 22 & 8.4387 & 10.63 & 3.21 & 3.05 & 2.75 & 129.02 & 41 & 46 & 47 \\
\hline 23 & 6.9138 & 15.65 & 3.11 & 2.96 & 6.74 & 100.84 & 58 & 55 & 55 \\
\hline 24 & 6.4676 & 5.32 & 1.04 & 1.14 & 7.87 & 100.16 & 39 & 39 & 39 \\
\hline 25 & 6.102 & 15.21 & 3.66 & 3.44 & 10.31 & 90.23 & 77 & 78 & 78 \\
\hline 26 & 5.3934 & 9.93 & 0.8 & 0.94 & 12.19 & 79.42 & 84 & 60 & 61 \\
\hline 27 & 6.9958 & 6.64 & 2.47 & 2.4 & 6.47 & 108.08 & 35 & 49 & 49 \\
\hline 28 & 7.1369 & 9.42 & 1.63 & 1.67 & 5.81 & 109.33 & 43 & 34 & 34 \\
\hline 29 & 8.2813 & 12.09 & 1.33 & 1.4 & 2.39 & 128.56 & 44 & 28 & 28 \\
\hline 30 & 6.2293 & 4.08 & 2.33 & 2.27 & 9.81 & 96.32 & 38 & 63 & 63 \\
\hline 31 & 7.1412 & 2.25 & 0.97 & 1.08 & 5.76 & 112.73 & 10 & 24 & 24 \\
\hline 32 & 5.6122 & 4.46 & 0.33 & 0.52 & 11.5 & 87.06 & 56 & 46 & 46 \\
\hline 33 & 6.7856 & 2.19 & 2.45 & 2.38 & 7.8 & 105.59 & 16 & 51 & 51 \\
\hline 34 & 5.7126 & 1.96 & 1.25 & 1.33 & 11.79 & 89.76 & 41 & 63 & 63 \\
\hline 35 & 6.8517 & 7.74 & 1.91 & 1.91 & 7.34 & 105.28 & 41 & 43 & 43 \\
\hline 36 & 6.0839 & 24.65 & 5.37 & 4.94 & 10.27 & 84.44 & 84 & 83 & 83 \\
\hline 37 & 6.3783 & 6.35 & 1.07 & 1.17 & 8.3 & 98.27 & 46 & 45 & 45 \\
\hline 38 & 6.3859 & 18.98 & 6.25 & 5.71 & 9.34 & 91.26 & 73 & 74 & 74 \\
\hline 39 & 6.4553 & 17.18 & 3.21 & 3.04 & 8.72 & 93.71 & 70 & 66 & 65 \\
\hline
\end{tabular}




\begin{tabular}{llllllllll}
\hline 40 & 6.1203 & 4.17 & 0.73 & 0.88 & 9.19 & 95.39 & 42 & 41 & 42 \\
41 & 5.845 & 8.75 & 2.06 & 2.04 & 10.73 & 86.99 & 72 & 70 & 70 \\
42 & 5.6884 & 7.6 & 0.41 & 0.6 & 10.85 & 85.13 & 68 & 47 & 47 \\
43 & 6.1086 & 3.06 & 2.16 & 2.13 & 10.27 & 95.78 & 38 & 64 & 64 \\
44 & 5.7454 & 4.84 & 1.04 & 1.15 & 10.86 & 88.83 & 54 & 59 & 59 \\
45 & 7.1106 & 12.1 & 2.62 & 2.53 & 6.21 & 106.83 & 50 & 48 & 48 \\
46 & 4.8054 & 2.62 & 0.29 & 0.48 & 15.53 & 75.32 & 57 & 53 & 53 \\
47 & 7.0409 & 10.33 & 2.22 & 2.18 & 6.07 & 106.56 & 47 & 43 & 43 \\
48 & 6.345 & 6.65 & 0.69 & 0.84 & 8.17 & 97.47 & 50 & 35 & 35 \\
49 & 5.1384 & 1.35 & 0.8 & 0.93 & 14.24 & 81.3 & 49 & 63 & 62 \\
50 & 7.3348 & 12.7 & 2.31 & 2.26 & 4.74 & 110.93 & 48 & 40 & 40 \\
51 & 6.1728 & 7.37 & 2.67 & 2.58 & 10.01 & 93.71 & 54 & 69 & 69 \\
52 & 6.0575 & 7.82 & 0.34 & 0.53 & 9.1 & 93.03 & 65 & 39 & 39 \\
53 & 8.2193 & 7.81 & 1.73 & 1.75 & 2.95 & 127.22 & 33 & 32 & 32 \\
\hline
\end{tabular}

Among the other stable genotypes, 33, 31, 7 and 24 occupied positions 13th, 5th, 16th and 19th in the productivity ranking, respectively. The last-place ranking of mean squares, i.e., the less stable genotype was 17, but that was positioned in the top 10 in productive performance, occupying the 9th position.

Other authors to also use the methodology of Yates and Cochran (1938), found that the most stable genotypes, were among the less productive, while the most productive were found to be the most unstable (Cargnelutti et al., 2007). This method values the stability in the biological sense, and some authors report not be advantageous to use this methodology because genotypes with that kind of stability are generally not productive (Cruz et al., 2012). Thus, using this methodology, it can be concluded that more stable cultivars are indicated, but associated with lower productivity.

Regarding the Plaisted and Peterson (1959) method, the genotype which has lower estimate $\theta(\%)$ is considered the most stable. As results shown in Table 4, the 20 genotypes were more stable in ascending order: 18, 2, 46, 32, $52,6,42,5,14,11,48,40,8,49,26,4,10,9,31$ and 24 . The most stable genotype by this method was 18 , which in the productivity ranking was in 33rd place (Table 4), with an average below the overall average. Daher et al. (2003), for genotypes 27 and 37 of this study, they found estimates $\theta(\%) 4.67 \%$ and $14.40 \%$, respectively. They also concluded that the genotypes with highest yield had little stability.

It was observed generally that classification for stability is not highly related with the worst production as in method Yates and Cochran, occurring alternate genotypes with good yields and stability, with low production genotypes, and good stability. Also identified genotypes with low yield and stability values. In Silva et al. (2017) evaluated the stability of the production of 40 elephant grass genotypes and found that the Mercker 86-México genotype presented the second best yield $\left(30.65 \mathrm{t} \mathrm{ha}^{-1}\right)$, but it was the most unstable according to the Yates and Cochran method, corroborating with the results obtained in the study in relation to this method.

The Wrickie (1965) method, like the previous one (Plaisted and Peterson) agreed that the most stable genotype has lower estimated $\omega \mathrm{i}(\%)$. Methods Plaisted and Peterson and Wricke showed a perfect correlation between them $(\mathrm{r}=1)$ (Table 6) and therefore identical correlations with the other methods. Thus, the findings obtained by these two methods are the same. This similarity results from the fact that both use the decomposition of the sum of squares of GE interaction in the derivation of their stability parameters (Cruz et al., 2012).

The method proposed by Lin and Binns (1988) quantifies how the genotype is close to ideal performance, referred to as a genotype with the highest yield in each of the environments studied. The lower the value of the parameter $\mathrm{Pi}$ for a given genotype, it is evident that it was close to the maximum achieved in each of the cuts (Daher et al., 2003). According to Table 5, the 20 genotypes showed the lowest Pi values in ascending order were: $29,22,53,50,31,28,47,45,27,23,16,17,35,6,7,33,24,48,37$ and 12. 
Table 5. Estimate stability parameters for dry matter production by means of Yates and Cochran (Y\&C), Plaisted and Peterson ( $\theta \%$ ), Wricke ( $\omega \mathrm{i} \%)$, Lin and Binns (LB), Annicchiarico (Ann \%) and Kang and Phan associated with Yates and Cochran $(\mathrm{K}+\mathrm{Y} \& \mathrm{C})$; Plaisted and Peterson $(\mathrm{K}+\theta \%)$ and Wricke $(\mathrm{K}+\mathrm{Wi})$ methods

\begin{tabular}{|c|c|c|c|c|c|c|c|c|c|}
\hline Genotype & Average & $\mathrm{Y} \& \mathrm{C}$ & $\theta(\%)$ & $\omega \mathrm{i}(\%)$ & LB & Ann(\%) & $\mathrm{K}+\mathrm{Y} \& \mathrm{C}$ & $\mathrm{K}+\theta(\%)$ & $\mathrm{K}+\mathrm{Wi}$ \\
\hline 1 & 17 & 49 & 49 & 49 & 23 & 22 & 40 & 41 & 42 \\
\hline 2 & 51 & 4 & 2 & 2 & 50 & 49 & 30 & 26 & 26 \\
\hline 3 & 53 & 9 & 32 & 32 & 53 & 53 & 36 & 52 & 52 \\
\hline 4 & 28 & 17 & 16 & 16 & 26 & 27 & 16 & 16 & 16 \\
\hline 5 & 36 & 10 & 8 & 8 & 33 & 32 & 17 & 17 & 17 \\
\hline 6 & 18 & 24 & 6 & 6 & 14 & 15 & 12 & 1 & 1 \\
\hline 7 & 16 & 18 & 40 & 40 & 15 & 12 & 4 & 30 & 30 \\
\hline 8 & 41 & 21 & 13 & 13 & 40 & 40 & 37 & 28 & 27 \\
\hline 9 & 47 & 33 & 18 & 18 & 47 & 48 & 50 & 40 & 40 \\
\hline 10 & 52 & 6 & 17 & 17 & 52 & 51 & 34 & 43 & 43 \\
\hline 11 & 25 & 22 & 10 & 10 & 21 & 20 & 19 & 7 & 7 \\
\hline 12 & 15 & 34 & 43 & 43 & 20 & 14 & 23 & 31 & 31 \\
\hline 13 & 35 & 41 & 23 & 23 & 30 & 36 & 48 & 32 & 32 \\
\hline 14 & 43 & 32 & 9 & 9 & 43 & 44 & 47 & 25 & 25 \\
\hline 15 & 45 & 11 & 30 & 30 & 45 & 43 & 31 & 48 & 48 \\
\hline 16 & 14 & 36 & 25 & 25 & 11 & 13 & 25 & 9 & 9 \\
\hline 17 & 9 & 53 & 53 & 53 & 12 & 18 & 38 & 35 & 35 \\
\hline 18 & 33 & 15 & 1 & 1 & 29 & 28 & 21 & 5 & 5 \\
\hline 19 & 21 & 45 & 48 & 48 & 27 & 25 & 41 & 44 & 44 \\
\hline 20 & 44 & 48 & 50 & 50 & 46 & 47 & 53 & 53 & 53 \\
\hline 21 & 49 & 19 & 27 & 27 & 51 & 52 & 42 & 49 & 49 \\
\hline 22 & 1 & 40 & 46 & 46 & 2 & 1 & 9 & 19 & 20 \\
\hline 23 & 11 & 47 & 44 & 44 & 10 & 16 & 35 & 29 & 29 \\
\hline 24 & 19 & 20 & 20 & 20 & 17 & 17 & 8 & 10 & 10 \\
\hline 25 & 31 & 46 & 47 & 47 & 36 & 34 & 49 & 50 & 50 \\
\hline 26 & 46 & 38 & 15 & 15 & 44 & 46 & 51 & 34 & 34 \\
\hline 27 & 10 & 25 & 39 & 39 & 9 & 7 & 5 & 23 & 23 \\
\hline 28 & 6 & 37 & 28 & 28 & 6 & 6 & 14 & 6 & 6 \\
\hline 29 & 2 & 42 & 26 & 26 & 1 & 2 & 15 & 3 & 3 \\
\hline 30 & 26 & 12 & 37 & 37 & 31 & 23 & 6 & 36 & 37 \\
\hline 31 & 5 & 5 & 19 & 19 & 5 & 4 & 1 & 2 & 2 \\
\hline 32 & 42 & 14 & 4 & 4 & 41 & 38 & 32 & 20 & 19 \\
\hline 33 & 13 & 3 & 38 & 38 & 16 & 10 & 2 & 24 & 24 \\
\hline 34 & 39 & 2 & 24 & 24 & 42 & 35 & 10 & 37 & 38 \\
\hline 35 & 12 & 29 & 31 & 31 & 13 & 11 & 11 & 14 & 14 \\
\hline 36 & 32 & 52 & 51 & 51 & 34 & 42 & 52 & 51 & 51 \\
\hline 37 & 23 & 23 & 22 & 22 & 19 & 19 & 18 & 18 & 18 \\
\hline 38 & 22 & 51 & 52 & 52 & 28 & 33 & 46 & 47 & 47 \\
\hline 39 & 20 & 50 & 45 & 45 & 22 & 29 & 44 & 42 & 41 \\
\hline 40 & 29 & 13 & 12 & 12 & 25 & 26 & 13 & 13 & 13 \\
\hline 41 & 37 & 35 & 33 & 33 & 37 & 39 & 45 & 46 & 46 \\
\hline 42 & 40 & 28 & 7 & 7 & 38 & 41 & 43 & 21 & 21 \\
\hline 43 & 30 & 8 & 34 & 34 & 35 & 24 & 7 & 39 & 39 \\
\hline 44 & 38 & 16 & 21 & 21 & 39 & 37 & 28 & 33 & 33 \\
\hline 45 & 7 & 43 & 41 & 41 & 8 & 8 & 26 & 22 & 22 \\
\hline 46 & 50 & 7 & 3 & 3 & 49 & 50 & 33 & 27 & 28 \\
\hline 47 & 8 & 39 & 35 & 35 & 7 & 9 & 20 & 15 & 15 \\
\hline 48 & 24 & 26 & 11 & 11 & 18 & 21 & 27 & 8 & 8 \\
\hline 49 & 48 & 1 & 14 & 14 & 48 & 45 & 24 & 38 & 36 \\
\hline 50 & 4 & 44 & 36 & 36 & 4 & 5 & 22 & 12 & 12 \\
\hline 51 & 27 & 27 & 42 & 42 & 32 & 30 & 29 & 45 & 45 \\
\hline 52 & 34 & 31 & 5 & 5 & 24 & 31 & 39 & 11 & 11 \\
\hline 53 & 3 & 30 & 29 & 29 & 3 & 3 & 3 & 4 & 4 \\
\hline
\end{tabular}


Table 6. Estimates of Spearman correlation coefficients among average dry matter production and stability parameters

\begin{tabular}{|c|c|c|c|c|c|c|c|c|}
\hline & $\mathrm{Y} \& \mathrm{C}$ & $\theta(\%)$ & Wi & $\mathrm{Pi}$ & Ann (\%) & $\mathrm{K}+\mathrm{Y} \& \mathrm{C}$ & $\mathrm{K}+\theta(\%)$ & $\mathrm{K}+\mathrm{Wi}$ \\
\hline Average & $0.43 * *$ & $0.46^{* *}$ & $0.46^{* *}$ & $-0.98 * *$ & $0.97 * *$ & $-0.54 * *$ & $-0.51 * *$ & $-0.51 * *$ \\
\hline $\mathrm{Y} \& \mathrm{C}$ & & $0.60 * *$ & $0.60 * *$ & $-0.38 * *$ & $0.24 \mathrm{~ns}$ & $0.50 * *$ & $0.14^{\mathrm{ns}}$ & $0.14^{\mathrm{ns}}$ \\
\hline$\theta(\%)$ & & & $1.00 * *$ & $-0.31 *$ & $0.30 *$ & $0.11 \mathrm{~ns}$ & $0.51 * *$ & $0.51 * *$ \\
\hline Wi & & & & $-0.31 *$ & $0.30 *$ & $0.11 \mathrm{~ns}$ & $0.51 * *$ & $0.51 * *$ \\
\hline $\mathrm{Pi}$ & & & & & $-0.97 * *$ & $0.56^{* *}$ & $0.64 * *$ & $0.64 * *$ \\
\hline Ann & & & & & & $-0.69 * *$ & $-0.63 * *$ & $-0.63 * *$ \\
\hline $\mathrm{K}+\mathrm{Y} \& \mathrm{C}$ & & & & & & & $0.60 * *$ & $0.60 * *$ \\
\hline $\mathrm{K}+\theta(\%)$ & & & & & & & & $1.00 * *$ \\
\hline
\end{tabular}

Note. $($ Y\&C) $=$ Yates and Cochran; $(\theta \%)=$ Plaisted and Peterson; $(\omega \mathrm{i} \%)=$ Wricke, Lin and Binns (LB), Annicchiarico (Ann \%) and Kang and Phan associated with Yates and Cochran (K+Y\&C); Plaisted and Peterson $(\mathrm{K}+\theta \%)$ and Wricke $(\mathrm{K}+\mathrm{Wi})$ methods. ${ }^{* *}$ and $*$ significant at the level of 1 and $5 \%$ of probability by $\mathrm{F}$ test, respectively.

Annicchiarico (1992) considers that all agriculture involves the occurrence of a certain event that is independent of the breeder's will, and that this can be measured to assist in decision making about the use of cultivars. For this, the author proposed a method of estimating a measure of stability called confidence index (I). The higher the index, the greater the confidence in the recommendation of the cultivar. The genotypes with the highest estimates I were $22,29,53,31,50,28,27,45,47,33,35,7,16,12,6,23,24$ (Table 5). They presented the stability parameter above $100 \%$, indicating that would yield above ambient average. A total of 17 genotypes, all of them are among the 20 most productive. The more is produced, the greater the confidence index.

The results obtained by the Annicchiarico (1992) methodology were very similar to those obtained by the Lin and Binns (1988) model, which was expected. Both are designed to measure the superior genotypes: the first takes as a reference the performance of the best genotypes in each environment and the second the average of each of the environments.

In this work, the weighting of Kang and Phan (1991) was made in relation to Yates and Cochran (1938); Plaisted and Peterson (1959) and Wricke (1965) methods. Kang and Phan method associated with the traditional method showed the genotypes $31,33,53,7,27,30,43,24,22,34,35,6,40,28,29,4,5,37,11$ and 47 as the 20 most stable. Among them, 12 are among the 20 most productive. Genotype 31 comes in 1 st position according to this method, and is the 5th place among the most productive (Table 5).

All correlation methods were correlated with DMP. However, correlation coefficients indicate that a relationship differs between methods. Stability parameters of Kang and Phan (1991) associated with Plaisted and Peterson (1959) and Wrickie (1965) methods indicated as top 20 the genotypes: 6, 31, 29, 53, 18, 28, 11, 48, 16, 24, 52, $50,40,35,47,4,5,37,32$ and 22. Among them, 11 were between the 20 most productive. The results for the methods are the same, they have perfect correlation with each other. Daher et al., 2003 using the same method with 14 clones and three cultivars, and the genotypes 27 (Mineiro) and 37 (Taiwan A-146) were also among them presenting a high value of Kang and Phan "ranks". In this work the genotypes 27 and 37 were between the top 25 among the 53 genotypes.

Phan and Kang (1991) associated with Plaisted and Peterson (1959) method was correlated with the average productivity and all methods $(\mathrm{P}<0.01)$, except the method of Yates and Cochran (1938). The same can be concluded with the method of Kang and Phan (1991) associated with Wrickie (1965) method, both of which have a correlation coefficient equal to 1 .

According to the estimates of the Spearman correlation coefficients (Table 6), the method of Yates and Cochran (1938), or traditional, showed a positive correlation $(\mathrm{r}=0.43)$ with the average level of $1 \%$ significance, indicating a weak tendency of individuals with little variation over the cuts have low production.

Correlations between the method of Yates and Cochran (1938) with Plaisted and Peterson, Wrickie, Lin and Bins and Kang and Phan method associated with this method (Yates and Cochran) were significant at 1\% $(\mathrm{r}=0.6 ; 0.6$; -0.38 and 0.5 ), respectively. On the other hand, the correlations with the methods of Annicchiarico and Kang and Phan associated with Peterson and Plaisted and Wrickie methods were not significant $(r=0.24 ; 0.14 ; 0.14)$, respectively. 
The Plaisted and Peterson (1959) method was positively correlated $(\mathrm{P}<0.01)$ to yield $(\mathrm{r}=0.43)$, with Wrickie $(\mathrm{r}$ $=1)$, and the Kang and Phan weights associated with Plaisted and Peterson method and Wrickie $(r=0: 51)$ according to Table 6, and also correlated with the Annicchiarico method $(r=0.30)(P<0.05)$. However, the correlation with Kang and Phan method associated with the Yates and Cochran $(\mathrm{r}=0.11)$ was not significant $(\mathrm{P}>$ $0.05)$ and with the method of Lin and Bins was negatively correlated $(\mathrm{r}=-0.31)(\mathrm{P}<0.05)$.

The methods Plaisted and Peterson and Wricke presented a perfect correlation between them $(r=1)$, thus exhibit the same correlation with the other methods. Regarding the correlation between the method Wrickie (1965) and crop productivity in this work it was found $\mathrm{r}=043$, similar to that found for Scapim et al. (2010) $(\mathrm{r}=0.36)$, according to Table 6 .

The method of Linn and Bins (Pi indices) presented high correlation with the average productivity of the genotypes, revealing estimate of $r=-0.98$, similar to that found by Scapim et al. (2010) $(r=-0.99)$. According to these same authors, the correlation values between the present method and the Wrickie (1965) was -0.35 , also in agreement with the value found in this study $(\mathrm{r}=-0.31)$.

The Annicchiarico method presented strong agreement with the average productivity, with correlation of 0.97 (P $<0.01)$. The more is produced, the greater the confidence index. The results obtained by the methodology of Annicchiarico (1992) were very similar to those obtained by the model Lin and Binns (1988). The Spearman correlation between Pi and Annicchiarico index was -0.97 (Table 6). These results are in agreement with those obtained by Mora et al. (2007), who also found concordant results in the two models to cotton productivity.

By using the Kang and Phan (1991) methodology, the method of Yates and Cochran (1938) was negatively correlated $(\mathrm{P}<0.01)$ with the average $(\mathrm{r}=-0.54)$, and the Plaisted and Peterson (1959) and Wricke (1965) methods found a correlation $(\mathrm{r}=0.11)$ that was not significant $(\mathrm{P}>0.05)$. Still on consideration of the effect of the Kang and Phan weights associated with Yates and Cochran (1938) method, a positive correlation was observed $(\mathrm{r}=0.56)(\mathrm{P}<0.01)$ with the Lin and Binns $(1988)$ stability parameters as well as there was a positive correlation with a weighting of Kang and Phan (1991) with methods Plaisted and Peterson (1959) and Wrickie (1965) and hence $r=0.6$ for both.

The use of Kang and Phan methodology (1991) associated with the method of Plaisted and Peterson (1959) presented correlation coefficient with an average of $-0.51(\mathrm{P}<0.01)$, in agreement with Scapim et al. (2010) that found value -0.57 . The weighting Kang and Phan (1991) associated with the method of Plaisted and Peterson (1959) was correlated with the average productivity and all methods in the $1 \%$ level, except for the method of Yates and Cochran (1938). The same may be concluded with Kang and Phan's (1991) method associated with Wrickie method (1965), both of which have a correlation coefficient equal to 1.

\section{Conclusions}

The most productive genotypes showed greater stability at Lin and Binns method, as in Annicchiarico method. These methods show a strong association between themselves and produced similar genotypic classifications on the phenotypic stability, recommending be used either.

The methods Plaisted and Peterson (1959), and Wrickie (1965) showed Spearman correlation equal to 1 indicating same stable genotypes.

Based among 20 genotypes of higher productivity and good stability parameters, it is concluded that the genotypes were more promising for feed use was Pusa Napier 2, Taiwan, A-143 and Merckeron Comum.

\section{Acknowledgements}

The authors would like to thank, the State University of Northern Fluminense Darcy Ribeiro (UENF), Agroenergy and Waste Management State Research Center (Pesagro-Rio), National Council for Scientific and Technological Development (CNPq), Coordination of Improvement of Higher Education Personnel (CAPES) and the Foundation for Research Support of the State of Rio de Janeiro (FAPERJ) for the financing of project.

\section{References}

Annicchiarico, P. (1992). Cultivar adaptation and recomendation from alfalfa trials in Northern Italy. Journal of Genetics and Plant Breeding, 46, 269-278. Retrieved from http://agris.fao.org/agris-search/search.do? recordID=IT9362063

Barcellos, A. O., Ramos, A. K. B., Vilela, L., \& Martha Junior, G. B. (2008). Sustentabilidade da produção animal baseada em pastagens consorciadas e no emprego de leguminosas exclusivas, na forma de banco de proteína, nos trópicos brasileiros. Revista Brasileira Zootecnia, 37, 51-67. https://doi.org/10.1590/ S1516-35982008001300008 
Cargnelutti Filho, A., Perecin, D., Malheiros, E. B., \& Guadagnin, J. P. (2007). Comparação de métodos de adaptabilidade e estabilidade relacionados à produtividade de grãos de cultivares de milho. Bragantia, 66, 571-578. https://doi.org/10.1590/S0006-87052007000400006

Cóser, A. C., Martins, C. E., Deresz, F., Freitas, A. F., Paciullo, D. S. C., Alencar, C. A. B., \& Vítor, C. M. T. (2008). Produção de forragem e valor nutritivo do capim-elefante, irrigado durante a época seca. Pesquisa Agropecuária Brasileira, 43, 1625-1631. https://doi.org/10.1590/S0100-204X2008001100023.

Cruz, C. D. (2013). GENES-A software package for analysis in experimental statistics and quantitative genetics. Acta Scientiarum. Agronomy, 35, 271-276. https://doi.org/10.4025/actasciagron.v35i3.21251

Cruz, C. D., Regazzi, A. J., \& Carneiro, P. C. S. (2012). Modelos biométricos aplicados ao melhoramento genético. Viçosa: UFV.

Daher, R. F., Pereira, M. G., Amaral, Jr. A. T., Pereira, A. V., Lédo, F. J. S., \& Daros, M. (2003). Estabilidade da produção forrageira em clones de capim-elefante (Pennisetum purpureum Schum.). Ciência Agrotecnologia, 27, 788-797. https://doi.org/10.1590/S1413-70542003000400007

Kang, M. S., \& Phan, H. N. (1991). Simultaneous selection for high yielding and stable crop genotypes. Agronomy Journal, 83, 161-165. https://doi.org/10.2134/agronj1991.00021962008300010037x

Leão, F. F., Cancellier, L. L., Pereira, A. V., Ledo, F. J. S., \& Afférri, F. S. (2012). Produção forrageira e composição bromatológica de combinações genômicas de capim-elefante e milheto. Revista Ciência Agronômica, 43, 368-375. Retrieved from http://ccarevista.ufc.br/seer/index.php/ccarevista/article/view/ $1128 / 699$

Lima, E. S., Silva, J. F. C., \& Vasquez, H. M. (2007). Produção de material seca e proteína bruta e relação folha/colmo de genótipos de capim-elefante aos 56 dias de rebrota. Revista Brasileira de Zootecnia, 36, 1518-1523. https://doi.org/10.1590/S1516-35982007000700009

Lin, C. S., \& Binns, M. R. (1988). A superiority measure of cultivar performance for cultivar $\times$ location data. Canadian Journal of Plant Science, 68, 193-198. https://doi.org/10.4141/cjps88-018

Lista, F. N. (2008). Avaliação de cultivares de capim-elefante (Pennisetum purpureum Schum.) para ruminantes na região Norte Fluminense (Tese Doutorado, Campos dos Goytacazes). Retrieved from http://www.dominiopublico.gov.br/pesquisa/DetalheObraForm.do?select_action=\&co_obra=125184

Meinerz, G. R., Olivo, C. J., Agnolin, C. A., Dullius, A. P., Moraes, R. S., Mombach, G., ... Machado, P. R. (2011). Produção e valor nutritivo da forragem de capim-elefante em dois sistemas de produção. Revista Brasileira de Zootecnia, 40, 2673-2680. https://doi.org/10.1590/S1516-35982011001200009

Mora, F., Pupim-Junior, O., \& Scapim, C. A. (2007). Prediction of cultivar effects on cotton yield in the presence of genotype environment interaction. Ciencia e Investigación Agraria, 34, 7-16. https://doi.org/10.4067/ S0718-16202007000100002

Moreira, P. C., Wascheck, R. C., Dutra, A. R., Grandsire, C., Almeida, O. C., Moreira, S. O. L., \& Oliveira, D. L. (2008). Utilização de capim-elefante para alimentação de bovinos. Estudos, 35, 429-449. Retrieved from http://seer.pucgoias.edu.br/index.php/estudos/article/view/743/563

Murakami, D. M., Cardoso, A. A., Cruz, C. D., \& Bizao, N. (2004). Considerações sobre duas metodologias de análise de estabilidade e adaptabilidade. Ciência Rural, 34, 71-78. https://doi.org/10.1590/S0103-84782 004000100011

Pimentel-Gomes, F. (2009). Curso de estatística experimental. Piracicaba: FEALQ.

Plaisted, R. L., \& Peterson, L. C. (1959). A technique for evaluating the ability of selections to yield consistently in different locations and seasons. American Potato Journal, 36, 381-385. https://doi.org/10.1007/BF028 52735

Scapim, C. A., Pacheco, C. A. P., Amaral Júnior, A. T., Vieira, R. A., Pinto, R. J. B., \& Conrado, T. V. (2010). Correlations between the stability and adaptability statistics of popcorn cultivars. Euphytica (Wageningen), 174, 209-218. https://doi.org/10.1007/s10681-010-0118-y

Schmildt, E. R., \& Cruz, C. D. (2005). Análise da adaptabilidade e estabilidade do milho pelos métodos de Eberhart e Russell (1966) e de Annicchiarico (1992). Revista Ceres, 52, 45-58. Retrieved from https://www.locus.ufv.br/bitstream/handle/123456789/20326/artigo.pdf?sequence=1\&isAllowed=y

Silva, D. S., \& Queiroz, A. C. (2004). Análise de Alimentos: Métodos químicos e biológicos. Editora UFV. 
Silva, V. B., Daher, R. F., Menezes, B. R. S., Oliveira, M. L. F., Araújo, M. S. B., \& Novo, A. A. C. (2017). Métodos de estabilidade diferentes para recomendação de cultivar em capim elefante para fins de energia no Brasil. Cerne, 23, 507-515. https://doi.org/10.1590/01047760201723042292

Souza, P. M., Ponciano N. J., Mata H. T. C., Brito M. N., \& Golinsk J. (2009). Padrão de desenvolvimento tecnológico dos municípios das Regiões Norte e Noroeste do Rio de Janeiro. Revista de Economia e Sociologia Rural, 47, 945-969. https://doi.org/10.1590/S0103-20032009000400007

Steel, R. G. D., Torrie, J. H., \& Dickey, D. A. (1997). Principles and procedures of statistics: A biometrical approach. New York: The McGraw-Hill Companies.

Viana, B. L., Mello, A. C. L., Lira, M. A., Guim, A., Dubeux, J. C. B., Santos, M. V. F., \& Cunha, M. V. (2014). Adaptability and Stability Analysis for Selection of Elephantgrass Clones under Grazing. Crop Science, 55, 950-957. https://doi.org/10.2135/cropsci2014.05.0406

Wricke, G. (1965). Zur berechnung der ökovalenz bei sommerweizen und hafer. Zeitschrift für Pflanzenzüchtung, $52,127-138$.

Yates, F., \& Cochran, W. G. (1938). The analysis of groups of experiments. Journal of Agricultural Science, 28, 556-580. https://doi.org/10.1017/S0021859600050978

\section{Copyrights}

Copyright for this article is retained by the author(s), with first publication rights granted to the journal.

This is an open-access article distributed under the terms and conditions of the Creative Commons Attribution license (http://creativecommons.org/licenses/by/4.0/). 